\title{
The state of nephrology in South Asia
}

Vivekanand Jha ${ }^{1,2}$, Harun Ur-Rashid ${ }^{3}$, Sanjay Kumar Agarwal ${ }^{4}$, Syed Fazal Akhtar ${ }^{5}$, Rishi Kumar Kafle $^{6}$, Rezvi Sheriff ${ }^{7}$, on behalf of the ISN South Asia Regional Board

${ }^{1}$ George Institute for Global Health India, New Delhi;

2University of Oxford, Oxford, UK.

${ }^{3}$ Kidney Foundation Hospital and Research Institute, Dhaka, Bangladesh

${ }^{4}$ All India Institute of Medical Sciences, New Delhi, India

${ }^{5}$ Sindh Institute of Urology and Transplantation, Karachi, Pakistan

${ }^{6}$ Medicare National Hospital \& Research Center, Kathmandu, Nepal

${ }^{7}$ National Hospital, Colombo, Sri Lanka

Corresponding author: Professor Vivekanand Jha, The George Institute for Global Health; 310-11 Elegance Tower, Jasola District Centre, New Delhi 110025 India. Tel: (+91)-11-415880-91 | Fax: (+91)-11-415-880-90. Email: vjha@georgeinstitute.org.in 


\begin{abstract}
Kidney disease attributable deaths and disability-adjusted life years have risen rapidly in South Asia. Diabetes is the commonest cause of kidney disease, but a substantial burden of disease is due to unmeasured risk-factors. Supported by governments, dialysis is growing but needs better oversight. The paper describes current service, training and research needs in the region.
\end{abstract}

Keywords: South Asia, Chronic kidney disease, Dialysis, Registry 
The South Asia region of the International Society of Nephrology comprises 8 countries (Table 1) with a combined population of 1.77 billion, about $29 \%$ of world population in 2016 . The World Bank classifies Afghanistan and Nepal as low-income and Bangladesh, Bhutan, India, Pakistan and Sri Lanka as low-middle income economies while Maldives is an upper middleincome country. Over $65 \%$ of the population in the region lives in rural areas.

Table 1 shows the development and health indicators of the South Asian countries. Notable are the relatively low health spending by the governments of three largest countries, the high out-of-pocket expenditure, low physician-to-population ratio (WHO recommended ratio: 1:1000); and high maternal, infant and under-5 mortality rates.

All the countries are characterised by large socio-economic inequities and regularly experience disasters - both natural (earthquakes, floods, droughts) and man-made (wars, conflicts) - which affects healthcare delivery, including that for kidney diseases. All countries in the region are in the bottom half of the list of 191 countries in terms of their Sociodemographic Index, developed by the Global Burden of Disease Study (Table 1).

Although non-communicable diseases (NCD) have taken primacy as the major causes of death and disability throughout the region, with the exception of Afghanistan, national policies for NCD control are in early stages of development and implementation. These policies are targeted to hypertension, diabetes, cardiovascular disease and common cancers. There is no stated policy for kidney disease screening and/or management in any South Asian country.

\section{Kidney disease burden in South Asia}

The Global Burden of Disease Study performs regular evaluation of disease burden in all regions of the world and provides modelled estimates for countries that do not have good quality primary data. Table 2 shows the estimated burden of kidney disease in South Asia in 2016 expressed as the numbers of deaths and disability adjusted life years (DALY), the ageadjusted death rate and the change compared to $1990^{1}$. The number of deaths and DALY has increased throughout the region, and more than doubled between 1990 and 2016 in India, Nepal, Pakistan and Afghanistan. The Million Death Study that established cause of death in a million households across India using a verbal autopsy tool, documented a rise of $>50 \%$ in 
the proportion of renal failure deaths to all deaths over a 10-year period (2001-03 and 2010$13)^{2}$. The rise was particularly notable in the Southern and Western states. Sub-national data are not available for other countries in the region.

Table 3 documents the rise in the incidence and prevalence numbers and rates of individuals with chronic kidney disease (CKD) in South Asia. The rise in the age-adjusted incidence and prevalence rates contrasts with a global trend, which has shown a decline. Deconvolution analysis has shown that most of the increase in the region is driven by population growth. ${ }^{1}$ In terms of cause; hypertension, diabetes and glomerulonephritis explain $60-75 \%$ rise in the CKD burden, the cause in the rest remains unascertained ${ }^{1}$. There is a significant departure from this trend in several parts of South Asia. Pockets have been described in Sri Lanka and India where CKD of uncertain etiology seems to be endemic. Accurate estimation of disease burden, epidemiology and identifying possible causes is a topic of research ${ }^{3}$. This condition largely affects farm workers who toil in hot and humid conditions and is akin in clinical presentation and course to Mesoamerican nephropathy. This observation suggests the need to develop kidney disease screening policies independent of those for hypertension and diabetes in the region.

The high burden of CKD-attributable deaths in the age range of $40-60$ years in South Asia has particular bearing on the economic status of families and societies to which the affected individuals belong, especially when the affected individual is the family bread-winner. According to a study amongst patients with end-stage kidney disease (ESKD) in India, even a short period at dialysis prior to getting a kidney transplantation resulted in catastrophic healthcare expenditure ( $>40 \%$ of non-food expense) in over $80 \%$ of patients, with the proportion exceeding $100 \%$ in about half, leading to distress financing - such as taking loans, selling of assets, etc ${ }^{4}$.

The burden of acute kidney injury (AKI) in the region has not been accurately estimated, but published literature indicates it to be high. Most AKI seen in public hospitals is acquired in the community, related to suboptimal sanitation and water quality, tropical infections and poor obstetric care. Delayed recognition and inappropriate treatment in the remote rural areas results in missed opportunities to prevent development of AKI. Delayed presentation to 
hospitals that can provide renal support results in high mortality and rates of residual renal dysfunction, as shown in the ISN 0 by 25 pilot project ${ }^{5}$. An implementation phase of a package of interventions developed in the project is currently underway in Dharan, Nepal.

\section{The landscape of nephrology service policy and manpower in South Asia.}

Table 4 shows the current service provisions for patients with kidney disease in the region. These data were collected from published and grey literature, reports in lay press, by surveying nephrology leaders in India Bangladesh, Nepal, Pakistan and Sri Lanka, and through personal contact with people knowledgeable about renal services in Afghanistan, Bhutan and Maldives. This high-level information does not include all metrics, and is unable adequately capture within-country variation.

The shortage of nephrologists throughout the region is evident. Dialysis is growing, with an estimate suggesting growth in excess of $30 \%$ per year in India. Sri Lanka, Maldives and Bhutan already have universal dialysis. The proportion of patients for AKI and ESKD who are able to get dialysis ranges from $<5 \%$ in Afghanistan and parts of other countries to 100 percent in Bhutan and some states in India. The Government of India announced a National Dialysis Service in 2016 to provide free dialysis to citizens below an income threshold, and according to the ability to pay for others, to be provided dialysis through district level dialysis units under public-private partnerships. Analysis of data from one such program that was instituted in 2008 showed that while such state-funded dialysis uncovered unmet need by showing progressive increase in uptake, the outcome was marred by high dropout rates, with about $60 \%$ of all subjects stopping dialysis within 6 months $^{6}$. This suggests existence of residual barriers to continued treatment - potential factors being lost wages, transport costs, cost of ancillary medications and management of medical complication and vascular access related issues. Anecdotal reports have also raised concerns regarding the quality of dialysis.

There is no stated policy for determining eligibility to RRT, or choice dialysis modality. Over $95 \%$ of dialysis patients are receiving hemodialysis (HD). Recent years have seen setting up of standalone HD units in small towns in India. These units are managed by independent organizations under public-private-partnership that offer economies of scale and 
opportunities for standardization of services, quality control and accountability. On the other hand, wars and conflict have prevented expansion of service in parts of South Asia.

There is a widespread perception that HD is cheaper than PD, but a recent health-economic analysis $^{7}$ from India showed the cost of HD to be several-fold greater than what was reported before, emphasizing the need for a proper health technology assessment of both dialysis modalities using the Thai model.

The availability of kidney transplantation is even more limited. Despite being the most costeffective renal replacement therapy, the number of transplants remains woefully low with respect to those who need it and is dependent on living donors, because of a combination of economic issues and shortage of effective large-scale deceased donation programs. In recent years, some Indian states have experienced an increase in organ retrieval rates from deceased donors. Increasing use of ABO-incompatible transplants, paired donation and swaps have also improved access.

Service provision in the region has been supported by not-for-profit organizations and charitable hospitals. A notable example is the Sind Institute of Urology and Transplant at Karachi, Pakistan (http://www.siut.org), that provides free lifelong care to a large number of patients with kidney disease using a model of partnership between government and philanthropy.

Insufficient number and uneven distribution of trained medical and paramedical professionals, properly equipped facilities and lack of guideline-driven treatment impacts all aspects of kidney care in the region. High quality but expensive care is provided in private hospitals to those who can afford it either through personal means or by employment-based insurance. Those without such cover (unorganised workers or self-employed) have to depend upon the limited number of oversubscribed public-sector facilities. Many private hospitals also provide care, especially kidney transplantation, to wealthy foreigners - especially those from Sub-Saharan Africa, middle east and central Asia. From time to time, various centers in India, Pakistan and Sri Lanka have indulged in large-scale commercial transplantation, both for domestic and foreign recipients. These were widely criticized and led to enactment of laws 
banning sale and purchase of organs. Clandestine cases of kidney sale continue to be reported, however. Worth pointing out is the intra-regional trafficking, with poor people being brought from Bangladesh and Nepal to India, Pakistan and Sri Lanka for sale of kidneys and rich people from India going to Pakistan and Sri Lanka to be transplanted ${ }^{8}$.

Basic laboratory services (qualitative urinalysis and serum creatinine) are available in most urban areas and are relatively cheap, but assay methodologies (e.g. serum creatinine) are not uniformly standardised. Proteinuria quantitation is available in fewer facilities. Specialized services like renal pathology and transplant immunology are also limited. Non-availability of immunofluorescence and electron microscopy constrains the ability to accurately diagnose and classify kidney disease. Facilities that collect blood and biopsy samples from small towns and have them analysed in central laboratories are improving service availability.

Widespread availability of generic medicines and biosimilars in the region has the potential to bring down the cost of treatment. By way of example, a vial of 4000 units of erythropoietin costs as little as US\$4 in India. On the other hand, some drugs like eculizumab are not available even to those who can afford it, forcing them to buy using clandestine routes.

\section{Nephrology Training and research in South Asia}

Active nephrology training programs are present in five countries but the number of nephrologists being produced remains low compared to the need. This is compounded by 'brain-drain' of trained nephrologists to industrialised countries. Training programs for paramedical staff (nurses, technicians) are also inadequate, given the rapidly growing demand. Capacity building in the region has been supported through ISN programs. In partnership with The American Nephrologists of Indian Origin (ANIO), the ISN runs a few special programs in the region (https://www.theisn.org/programs/isn-anio-partnership). They are Clinical Nephropathology Certificate Program, initially intended for the region but later opened to wider ISN membership in view of the high demand; the Scientific Writing Academy Course in which aspiring candidates are taught skills in designing, implementing and publishing clinical research in nephrology; and the The Indukaka Ipcowala Advanced Apprenticeship Program, which enables physicians or allied healthcare personnel from India to gain specific skills through practical experience. 
National nephrology societies are present in Bangladesh, India, Nepal, Pakistan and Sri Lanka and all are affiliated with the ISN. The Indian Society of Nephrology also has four zonal chapters.

Research in nephrology has been dominated by epidemiological studies describing the pattern of different diseases. In recent years, randomised controlled trials have been conducted for several conditions. Basic laboratory research is limited to a handful of institutions in India, with few PhDs focussing on kidney diseases. Other notable studies have examined the performance of the existing creatinine-based GFR estimating equations in South Asian populations and found them to be inaccurate. In the largely vegetarian Indian population, they overestimate the actual GFR, perhaps related to lower muscle mass. The Indian Chronic Kidney Disease Cohort study ${ }^{9}$, funded by the Department of Biotechnology, Government of India is following and collecting biosamples from about 5000 subjects with early stage CKD, and is a member of the ISN iNET-CKD program.

Funding for research in nephrology is available through government funding schemes in India and to some extent in Nepal and Pakistan. Government of Sri Lanka is supporting research in CKD of undetermined etiology. The Indian Society of Nephrology supports capacity building and research programs in South Asia directly and through partnership with ISN.

There are no active renal disease registries in the region. The Indian Society of Nephrology had initiated a hospital-based cross-sectional CKD Registry which is currently dormant. Efforts to establish national ESKD registries are underway in Bangladesh, India and Sri Lanka.

A recent online survey, sent to over 2400 nephrologists in the region and completed by 334 , identified top priorities for the ISN in the region (Fig 1).

To conclude, renal services in South Asia are characterized by increasing disease burden, and a rapidly growing demand for service and research in the face of inadequate financial and manpower capacity. Increasing number of training programs, growing government support 
to RRT, availability of cheap generic medicines and development of locally appropriate models of service delivery offer hope for the future of nephrology in the region.

\section{Conflict of interest}

VJ serves on Steering Committee for a trial funded by GlaxoSmithKline and serves on an advisory board and/or has spoken at scientific meetings for Biocon, Baxter, Janssen, Medtronic, and NephroPlus. He has a policy of all honoraria being paid to his employer. The other authors declared no competing interests. 


\section{References}

1. Xie Y, Bowe B, Mokdad A, Xian H, Yan Y, Li T, Maddukuri G, Tsai C-Y, Floyd T, Al-Aly, Z. The Global, Regional, and National State of Chronic Kidney Disease Epidemiology from 1990 to 2016: An analysis of the Global Burden of Disease Study. Kidney Int 2018;94:567-581

2. Dare AJ, Hang Fu S, Patra J, Rodriguez PS, Thakur JS, Jha P. Renal failure deaths and their risk factors in India 2001-13: nationally representative estimates from the Million Death Study. Lancet Glob Health. 2016; 5: 89-95

3. Abraham G, Varughese S, Thandavan T, Iyengar A, Fernando E, Naqvi SA, Sheriff R, UrRashid H, Gopalakrishnan N, Kafle RK. Chronic kidney disease hotspots in developing countries in South Asia. Clin Kidney J. 2016 Feb;9(1):135-41.

4. Ramachandran R, Jha V. Kidney transplantation is associated with catastrophic out of pocket expenditure in India. PLoS One 2013; 8(7): e67812.

5. Mehta RL, Cerdá J, Burdmann EA, Tonelli M, García-García G, Jha V, Susantitaphong P, Rocco M, Vanholder R, Sever MS, Cruz D, Jaber B, Lameire NH, Lombardi R, Lewington A, Feehally J, Finkelstein F, Levin A, Pannu N, Thomas B, Aronoff-Spencer E, Remuzzi G*. International Society of Nephrology's Oby25 initiative for acute kidney injury (zero preventable deaths by 2025): a human rights case for nephrology. Lancet. 2015 Jun 27;385(9987):2616-43

6. Shaikh M, Woodward M, John O, Bassi A, Jan S, Sahay M, Taduri G, Gallagher M, Knight J, Jha V. Utilization, costs and outcomes for patients on publicly funded hemodialysis in India. Kidney Int, 2018;94:440-445

7. Kaur G, Prinja S, Ramachandran R, Malhotra P, Gupta KL, Jha V. Cost of hemodialysis in a public-sector tertiary hospital of India. Clinical Kidney Journal sfx152, published Ahead of Print 25 January 2018

8. Jha V. Towards achieving national self-sufficiency in organ donation in India - A call to action. Indian J Nephrol. 2014 Sep;24(5):271-5.

9. Kumar V, Yadav AK, Gang S, John O, Modi GK, Ojha JP, Pandey R, Parameswaran S, Prasad N, Sahay M, Varughese S, Baid-Agarwal S, Jha V. Indian chronic kidney disease study: Design and methods. Nephrology (Carlton). 2017 Apr;22(4):273-278. 
Figure 1:

Survey results for ISN priorities in the South Asia region. Length of bars indicates percent of responders 
Table 1: General demographic, economic and health indicators of countries in South Asia

\begin{tabular}{|c|c|c|c|c|c|c|c|c|}
\hline Indicator & Afghanistan & Bangladesh & Bhutan & India & Maldives & Nepal & Pakistan & Sri Lanka \\
\hline Population (millions) & 34.7 & 162.5 & 0.8 & 1324.2 & 0.4 & 29 & 193.2 & 21.2 \\
\hline Percentage of rural population & 73 & 65 & 61 & 67 & 53 & 81 & 61 & 82 \\
\hline Life expectancy at birth, total (years) & 63.7 & 72.5 & 70.2 & 68.6 & 77.3 & 70.3 & 66.5 & 75.3 \\
\hline $\begin{array}{l}\text { Population growth } \\
\text { (annual \%) }\end{array}$ & 2.7 & 1.1 & 1.3 & 1.1 & 2.2 & 1.1 & 2 & 1.1 \\
\hline $\begin{array}{l}\text { Mortality rate, infant } \\
\text { (per } 1,000 \text { live births) }\end{array}$ & 53.2 & 28.2 & 26.8 & 34.6 & 7.3 & 28.4 & 64.2 & 8 \\
\hline Birth rate, crude (per 1,000 people) & 48.9 & 18.9 & 18.2 & 19 & 18.3 & 19.7 & 28.2 & 15.3 \\
\hline $\begin{array}{l}\text { Cause of death, by non- } \\
\text { communicable diseases (\% of total) }\end{array}$ & 33.2 & 66.9 & 67.8 & 60.8 & 78.4 & 64.5 & 56.4 & 79.7 \\
\hline $\begin{array}{l}\text { GDP per capita, PPP } \\
\text { (current international \$) }\end{array}$ & 1944.1 & 3579.8 & 8245.6 & 6127.3 & 14595 & 2464.4 & 5235.5 & 12313 \\
\hline $\begin{array}{l}\text { Current health expenditure } \\
\text { (\% of GDP) }\end{array}$ & 10.3 & 2.6 & 3.5 & 3.9 & 11.5 & 6.1 & 2.7 & 3 \\
\hline $\begin{array}{l}\text { Domestic general government health } \\
\text { expenditure per capita (current } \\
\text { international \$) }\end{array}$ & 9.5 & 12.9 & 207 & 61 & 1235 & 26 & 37 & 190 \\
\hline $\begin{array}{l}\text { Out-of-pocket expenditure } \\
\text { (\% of current health expenditure) }\end{array}$ & 78.4 & 71.8 & 19.8 & 65.1 & 16.4 & 60.4 & 34.9 & 66 \\
\hline $\begin{array}{l}\text { Number of physicians } \\
\text { (per } 1,000 \text { people) }\end{array}$ & 0.3 & 0.5 & 0.4 & 0.8 & 3.6 & 0.6 & 1 & 0.9 \\
\hline $\begin{array}{l}\text { Maternal mortality ratio (modeled } \\
\text { estimate, per } 100,000 \text { live births) }\end{array}$ & 396 & 176 & 148 & 174 & 68 & 258 & 178 & 30 \\
\hline $\begin{array}{l}\text { Mortality rate, under- } 5 \\
\text { (per } 1,000 \text { live births) }\end{array}$ & 70.4 & 34.2 & 32.4 & 45.2 & 8.5 & 34.5 & 78.8 & 9.4 \\
\hline Health access quality ${ }^{1}$ & 26 & 47.6 & 47.3 & 41.2 & 70.4 & 40 & 37.6 & 70.6 \\
\hline Social development index ${ }^{2}$ & 0.28 & 0.51 & 0.59 & 0.58 & 0.69 & 0.45 & 0.52 & 0.70 \\
\hline
\end{tabular}


${ }^{1}$ Health access quality (0-100): measures personal access to healthcare and its quality, derived from outcomes of 32 diseases that can be avoided or effectively treated with proper medical care

${ }^{2}$ Social development index (0-1): measures development status of countries based on average income per person, educational attainment and total fertility rate.

Data from The World Development Report 2016 (https://data.worldbank.org/products/wdi), the Global Burden of Disease Study 2016

(http://www.healthdata.org/gbd), the World Health Organization Global Health Observatory (http://www.who.int/gho/countries/en/) and ClA World

Factbook (https://www.cia.gov/library/publications/resources/the-world-factbook/). 


\section{Table 2: Deaths and DALYSs attributable to chronic kidney disease in South Asia}

\begin{tabular}{|c|c|c|c|c|c|c|c|c|}
\hline \multirow[t]{2}{*}{ Country } & \multicolumn{4}{|c|}{ Death } & \multicolumn{4}{|c|}{ DALY } \\
\hline & $\begin{array}{l}\text { Death number } \\
(95 \% \mathrm{Cl})\end{array}$ & $\begin{array}{l}\text { Percentage } \\
\text { Change } \\
\text { from } 1990\end{array}$ & $\begin{array}{l}\text { Death rate* } \\
(95 \% \mathrm{Cl})\end{array}$ & $\begin{array}{l}\text { Percentage } \\
\text { Change } \\
\text { from } 1990\end{array}$ & $\begin{array}{l}\text { DALY number } \\
(95 \% \mathrm{Cl})\end{array}$ & $\begin{array}{l}\text { Percentage } \\
\text { Change } \\
\text { from } 1990\end{array}$ & $\begin{array}{l}\text { DALY rate* } \\
(95 \% \mathrm{Cl})\end{array}$ & $\begin{array}{l}\text { Percentage } \\
\text { Change } \\
\text { from } 1990\end{array}$ \\
\hline Afghanistan & $\begin{array}{l}8,047.65 \\
(6,107.86- \\
10,520.70)\end{array}$ & $197.14 \%$ & $\begin{array}{l}24.09 \\
(18.29- \\
31.50)\end{array}$ & $6.08 \%$ & $\begin{array}{l}303,585.14 \\
(240,986.39- \\
385,770.84)\end{array}$ & $170.34 \%$ & $\begin{array}{l}908.89 \\
(721.48- \\
1,154.94)\end{array}$ & $-3.49 \%$ \\
\hline Bangladesh & $\begin{array}{l}19,309.40 \\
(17,172.69- \\
22,100.74)\end{array}$ & $34.80 \%$ & $\begin{array}{l}11.93 \\
(10.61- \\
13.65)\end{array}$ & $-13.25 \%$ & $\begin{array}{l}597,889.43- \\
761,354.99)-\end{array}$ & $3.36 \%$ & $\begin{array}{l}418.20 \\
(369.31- \\
470.29)\end{array}$ & $-37.81 \%$ \\
\hline Bhutan & $\begin{array}{l}116.40 \\
(88.70- \\
147.89)\end{array}$ & $55.45 \%$ & $\begin{array}{l}14.59 \\
(11.12- \\
18.53)\end{array}$ & $3.51 \%$ & $\begin{array}{l}958.62 \\
(3,123.42- \\
4,885.80)\end{array}$ & $19.10 \%$ & $\begin{array}{l}496.11 \\
(391.44- \\
612.31)\end{array}$ & $-20.70 \%$ \\
\hline India & $\begin{array}{l}234,345.34 \\
(218,550.67- \\
263,799.70)\end{array}$ & $102.20 \%$ & $\begin{array}{l}17.81 \\
(16.61- \\
20.05)\end{array}$ & $32.72 \%$ & $\begin{array}{l}7,672,012.62 \\
(7,093,872.92 \\
- \\
8,511,010.07)\end{array}$ & $70.79 \%$ & $\begin{array}{l}582.96 \\
(539.03- \\
646.72)\end{array}$ & $12.10 \%$ \\
\hline Maldives & $\begin{array}{l}70.75 \\
(57.78-86.32)\end{array}$ & $25.48 \%$ & $\begin{array}{l}19.48 \\
(15.91- \\
23.76)\end{array}$ & $-30.82 \%$ & $\begin{array}{l}1,748.43 \\
(1,463.97- \\
2,116.26)-\end{array}$ & $19.92 \%$ & $\begin{array}{l}481.30 \\
(402.99- \\
582.55)\end{array}$ & $-55.85 \%$ \\
\hline Nepal & $\begin{array}{l}4,442.31 \\
(3,603.75- \\
5,516.60)\end{array}$ & $103.44 \%$ & $\begin{array}{l}14.77 \\
(11.98- \\
18.34)\end{array}$ & $26.81 \%$ & $\begin{array}{l}52,320.59 \\
(126,621.17- \\
183,707.93)\end{array}$ & $60.11 \%$ & $\begin{array}{l}506.44 \\
(420.99- \\
610.80)\end{array}$ & $-0.20 \%$ \\
\hline Pakistan & $\begin{array}{l}29,578.94 \\
(22,568.25- \\
41,217.38)\end{array}$ & $125.28 \%$ & $\begin{array}{l}15.49 \\
(11.82- \\
21.58)\end{array}$ & $27.75 \%$ & $\begin{array}{l}1,059,187.18 \\
(839,066.31- \\
1,393,716.39)\end{array}$ & $100.55 \%$ & $\begin{array}{l}554.67 \\
(439.39- \\
729.85)\end{array}$ & $13.73 \%$ \\
\hline Sri Lanka & $4,476.42$ & $84.63 \%$ & 21.60 & $54.47 \%$ & $114,768.35$ & $49.29 \%$ & 553.91 & $24.91 \%$ \\
\hline
\end{tabular}


* per 100,000 persons

Source: Xie et al, Kidney Int 2018 ${ }^{1}$; (data from Global Burden of Disease Study 2016) 
Table 3: The incidence and prevalence of chronic kidney disease in 2016 and change from 1990 in South Asian countries

\begin{tabular}{|c|c|c|c|c|c|c|c|c|}
\hline \multirow[t]{2}{*}{ Country } & \multicolumn{4}{|c|}{ Incidence } & \multicolumn{4}{|c|}{ Prevalence } \\
\hline & $\begin{array}{l}\text { CKD incidence } \\
\text { number } \\
(95 \% \mathrm{Cl})\end{array}$ & $\begin{array}{l}\text { Percentage } \\
\text { Change } \\
\text { from } 1990\end{array}$ & $\begin{array}{l}\text { CKD Incidence } \\
\text { rate* }^{*}(95 \% \mathrm{Cl})\end{array}$ & $\begin{array}{l}\text { Percentage } \\
\text { Change } \\
\text { from } 1990\end{array}$ & $\begin{array}{l}\text { Prevalence } \\
\text { number } \\
(95 \% \mathrm{Cl})\end{array}$ & $\begin{array}{l}\text { Percentage } \\
\text { Change } \\
\text { from } 1990\end{array}$ & $\begin{array}{l}\text { CKD } \\
\text { Prevalence } \\
\text { rate* } \\
(95 \% \mathrm{Cl})\end{array}$ & $\begin{array}{l}\text { Percentage } \\
\text { Change } \\
\text { from } 1990\end{array}$ \\
\hline Afghanistan & $\begin{array}{l}95,665.06 \\
(85,430.26- \\
107,258.13)\end{array}$ & $204.68 \%$ & $\begin{array}{l}286.41 \\
(255.77- \\
321.12)\end{array}$ & $8.77 \%$ & $\begin{array}{l}1,191,489.08 \\
(1,076,151.49 \\
- \\
1,322,367.96)\end{array}$ & $201.68 \%$ & $\begin{array}{l}3,567.14 \\
(3,221.84- \\
3,958.98)\end{array}$ & $7.70 \%$ \\
\hline Bangladesh & $\begin{array}{l}418,831.07 \\
(374,705.87- \\
464,290.14)\end{array}$ & $108.64 \%$ & $\begin{array}{l}258.71 \\
(231.45- \\
286.79)\end{array}$ & $34.27 \%$ & $\begin{array}{l}5,842,741.81 \\
(5,324,591.42 \\
- \\
6,378,595.38)\end{array}$ & $118.54 \%$ & $\begin{array}{l}3,609.03 \\
(3,288.97- \\
3,940.03)\end{array}$ & $40.63 \%$ \\
\hline Bhutan & $\begin{array}{l}1,987.09 \\
(1,774.91- \\
2,226.54)\end{array}$ & $79.36 \%$ & $\begin{array}{l}249.03 \\
(222.44- \\
279.04)\end{array}$ & $19.43 \%$ & $\begin{array}{l}27,752.18 \\
(25,209.21- \\
30,592.90)\end{array}$ & $90.73 \%$ & $\begin{array}{l}3,478.01 \\
(3,159.31- \\
3,834.02)\end{array}$ & $27.00 \%$ \\
\hline India & $\begin{array}{l}3,349,963.43 \\
(2,956,051.78- \\
3,749,342.24)\end{array}$ & $98.30 \%$ & $\begin{array}{l}254.55 \\
(224.62- \\
284.90)\end{array}$ & $30.15 \%$ & $\begin{array}{l}44,099,793.56 \\
(39,990,066.03 \\
- \\
48,562,284.69)\end{array}$ & $92.19 \%$ & $\begin{array}{l}3,350.96 \\
(3,038.67- \\
3,690.04)\end{array}$ & $26.15 \%$ \\
\hline Maldives & $\begin{array}{l}493.07 \\
(444.33- \\
544.54)\end{array}$ & $54.78 \%$ & $\begin{array}{l}135.73 \\
(122.31- \\
149.90)\end{array}$ & $-14.66 \%$ & $\begin{array}{l}6,946.18 \\
(6,323.53- \\
7,558.77)\end{array}$ & $67.68 \%$ & $\begin{array}{l}1,912.10 \\
(1,740.70- \\
2,080.73)\end{array}$ & $-7.55 \%$ \\
\hline Nepal & $\begin{array}{l}106,355.62 \\
(93,652.50- \\
119,600.80)\end{array}$ & $124.22 \%$ & $\begin{array}{l}353.61 \\
(311.38- \\
397.65)\end{array}$ & $39.77 \%$ & $\begin{array}{l}1,456,668.36 \\
(1,314,791.14 \\
- \\
1,603,419.54)\end{array}$ & $130.28 \%$ & $\begin{array}{l}4,843.16 \\
(4,371.44- \\
5,331.08)\end{array}$ & $43.54 \%$ \\
\hline Pakistan & $331,921.24$ & $121.36 \%$ & 173.82 & $25.53 \%$ & 4,599,729.69 & $124.88 \%$ & $2,408.75$ & $27.53 \%$ \\
\hline
\end{tabular}




\begin{tabular}{|c|c|c|c|c|c|c|c|c|}
\hline & $\begin{array}{l}(299,429.68 \text { - } \\
364,867.42)\end{array}$ & & $\begin{array}{l}(156.80 \text { - } \\
191.07)\end{array}$ & & $\begin{array}{l}(4,199,317.26 \\
- \\
5,059,163.48)\end{array}$ & & $\begin{array}{l}(2,199.06- \\
2,649.34)\end{array}$ & \\
\hline Sri Lanka & $\begin{array}{l}40,996.72 \\
(36,496.12- \\
45,756.88)\end{array}$ & $99.07 \%$ & $\begin{array}{l}197.86 \\
(176.14- \\
220.84)\end{array}$ & $66.55 \%$ & $\begin{array}{l}584,511.75 \\
(529,368.16- \\
646,473.78)\end{array}$ & $94.04 \%$ & $\begin{array}{l}2,821.03 \\
(2,554.89- \\
3,120.08)\end{array}$ & $62.35 \%$ \\
\hline
\end{tabular}

\section{*Per 100,000 persons}

Source: Xie et al, Kidney Int 2018 ${ }^{1}$; (data from Global Burden of Disease Study 2016) 
Table 4: The current landscape of nephrology service, policy, manpower and training in South Asia

\begin{tabular}{|c|c|c|c|c|c|c|c|c|}
\hline Indicator & Afghanistan & Bangladesh & Bhutan & India & Maldives & Nepal & Pakistan & Sri Lanka \\
\hline Number of nephrologists & $<10$ & 123 & 1 & 1,639 & $<5$ & 50 & 151 & 30 \\
\hline \multicolumn{9}{|l|}{ Is PD available? } \\
\hline Acute & $\begin{array}{r}\text { Yes, in some } \\
\text { cities }\end{array}$ & $\begin{array}{r}\text { Yes, all } \\
\text { administrative } \\
\text { divisions }\end{array}$ & No & $\begin{array}{r}\text { Yes, all states } \\
\text { and union } \\
\text { territories }\end{array}$ & $\begin{array}{l}\text { Not } \\
\text { known }\end{array}$ & $\begin{array}{r}1 / 7 \\
\text { provinces }\end{array}$ & $6 / 8$ units & $\begin{array}{r}\text { Yes, all } \\
\text { provinces }\end{array}$ \\
\hline Chronic & No & $\begin{array}{r}1 / 8 \\
\text { administrative } \\
\text { divisions }\end{array}$ & No & $\begin{array}{r}21 / 29 \text { states } \\
\& 4 / 7 \text { union } \\
\text { territories }\end{array}$ & No & $\begin{array}{r}1 / 7 \\
\text { provinces }\end{array}$ & $2 / 8$ units & $3 / 9$ provinces \\
\hline Is HD available? & $\begin{array}{r}\text { Yes, in some } \\
\text { cities }\end{array}$ & $\begin{array}{r}\text { Yes, all } \\
\text { administrative } \\
\text { divisions }\end{array}$ & Yes & $\begin{array}{r}\text { Yes, all states } \\
\text { and union } \\
\text { territories }\end{array}$ & Yes & $\begin{array}{r}\text { Yes, all } \\
\text { provinces }\end{array}$ & $6 / 8$ units & $\begin{array}{r}\text { Yes, all } \\
\text { provinces }\end{array}$ \\
\hline $\begin{array}{l}\text { What proportion of patients who } \\
\text { need are able to get dialysis for } \\
\text { ESKD }\end{array}$ & $<5 \%$ & $25 \%$ & $100 \%$ & $5-100 \%$ & $\begin{array}{r}\text { Not } \\
\text { known }\end{array}$ & $20 \%$ & $5-15 \%$ & $2-12 \%$ \\
\hline $\begin{array}{l}\text { Number of patients on chronic } \\
\text { dialysis }\end{array}$ & 5000 & 18,000 & 140 & 174,478 & $\begin{array}{r}\text { Not } \\
\text { known }\end{array}$ & 2,877 & $\begin{array}{r}8,381 \text { (data } \\
\text { NA from } 2 \\
\text { units) }\end{array}$ & 5,482 \\
\hline $\begin{array}{l}\text { Proportion of dialysis patients on } \\
\text { PD (\%) }\end{array}$ & 0 & 3 & $<1$ & $<5$ & $<1$ & 7 & $<1$ & \\
\hline Is Transplantation available? & $\begin{array}{r}\text { Sporadic. } \\
\text { Patients } \\
\text { travel } \\
\text { overseas }\end{array}$ & $\begin{array}{r}1 / 8 \\
\text { administrative } \\
\text { divisions. } \\
\text { Patients } \\
\text { travel } \\
\text { overseas }\end{array}$ & $\begin{array}{r}\text { No. } \\
\text { Patients } \\
\text { travel } \\
\text { overseas }\end{array}$ & $\begin{array}{r}\text { In } 16 \text { states } \\
\& 4 \text { union } \\
\text { territories }\end{array}$ & $\begin{array}{r}\text { No. } \\
\text { Patients } \\
\text { travel } \\
\text { overseas }\end{array}$ & $\begin{array}{r}1 / 7 \\
\text { provinces. } \\
\text { Patients also } \\
\text { travel } \\
\text { overseas }\end{array}$ & $5 / 8$ units & $4 / 9$ provinces \\
\hline $\begin{array}{l}\text { Is there an active deceased } \\
\text { donor program? }\end{array}$ & No & No & No & $\begin{array}{l}13 / 29 \text { states } \\
\& 3 / 7 \text { union } \\
\text { territories }\end{array}$ & No & $\begin{array}{r}1 / 7 \\
\text { provinces }\end{array}$ & $3 / 8$ units & $3 / 9$ provinces \\
\hline $\begin{array}{l}\text { Number of kidney transplants in } \\
\text { one year }\end{array}$ & Not known & 130 & 0 & 6,857 & 0 & 312 & 476 & 267 \\
\hline
\end{tabular}




\begin{tabular}{|c|c|c|c|c|c|c|c|c|}
\hline $\begin{array}{l}\text { Do nephrologists make AV } \\
\text { fistulas? }\end{array}$ & No & $\begin{array}{r}\text { Yes, in } 1 \\
\text { center }\end{array}$ & No & $\begin{array}{r}\text { Yes, about } \\
40 \%\end{array}$ & $\begin{array}{l}\text { Not } \\
\text { known }\end{array}$ & $\begin{array}{r}1 / 7 \\
\text { provinces }\end{array}$ & $\begin{array}{r}\text { Occasionally, } \\
1 / 8 \text { units }\end{array}$ & No \\
\hline $\begin{array}{l}\text { Do nephrologists put in PD } \\
\text { catheters? }\end{array}$ & No & $\begin{array}{r}\text { Yes, in } 1 \\
\text { center }\end{array}$ & No & $\begin{array}{r}\text { Yes, about } \\
20 \%\end{array}$ & $\begin{array}{l}\text { Not } \\
\text { known }\end{array}$ & $\begin{array}{r}1 / 7 \\
\text { provinces }\end{array}$ & $\begin{array}{r}6 / 8 \text { units, } \\
\text { mostly acute }\end{array}$ & $\begin{array}{r}\text { Yes, all } \\
\text { provinces }\end{array}$ \\
\hline Number of dialysis units & $<10$ & 101 & 3 & 1,584 & $<5$ & 53 & 121 & 29 \\
\hline Number of dialysis machines & 200 & 1179 & 8 & 12,881 & $<40$ & 410 & 481 & 274 \\
\hline Number of transplant centers & 1 & 6 & 0 & 233 & 0 & $\begin{array}{r}4-\text { all in } 1 \\
\text { province }\end{array}$ & 16 & 7 \\
\hline Funding for dialysis & Private & Mixed & $\begin{array}{l}\text { State- } \\
\text { funded }\end{array}$ & Mixed* & Private & State-funded & Mixed & State-funded \\
\hline Funding for transplant & Private & Mixed & State & Mixed $^{\dagger}$ & Private & State & Mixed & State \\
\hline $\begin{array}{l}\text { What is the OOPE}{ }^{1} \text { on } \\
\text { dialysis/transplant (scale of } 0-10 \text { ) }\end{array}$ & $9 * *$ & 8 & & $0-10$ & 8 & - & $3-8$ & 3 \\
\hline $\begin{array}{l}\text { Kidney disease treatment } \\
\text { guidelines }\end{array}$ & No & No & No & Yes & No & No & No & No \\
\hline $\begin{array}{l}\text { Number of nephrology training } \\
\text { centers }\end{array}$ & 0 & 6 & 0 & 72 & 0 & 4 & 34 & 9 \\
\hline $\begin{array}{l}\text { Number of trainees enrolled in } \\
\text { nephrology training programs } \\
\text { every year }\end{array}$ & 0 & 35 & 0 & 136 & 0 & 5 & 56 & 19 \\
\hline $\begin{array}{l}\text { National/regional dialysis or } \\
\text { kidney disease registries }\end{array}$ & No & No & No & No & No & No & No & No \\
\hline
\end{tabular}

*Mixed: various combinations of state funded, employment-based insurance, private insurance, charity (to the patient or dialysis facility), and out of pocket payment.

** state funding started recently.

tFree in public hospitals for the poor; the insured can get in empanelled private hospitals.

${ }^{1}$ ESKD: End-stage kidney disease; OOP: Out-of-pocket expenditure on 0-10 scale, where 0 indicates no OOPE, whereas 10 indicates catastrophic OOPE (>40\% of non-food expenditure) and distress financing (loss or sale of assets, borrowing)

Data from survey of academic nephrology centers and leaders using ISN Global Kidney Health Atlas methodology. 
